\title{
Societal Responses and Household-Level Determinants of Coronavirus Preparedness in Rural Ethiopia
}

Yonnas Addis ( $\sim$ yonnasaddis19@gmail.com )

Wolkite University

Dubale Abate

Wolkite University

João Batista

Federal University of Larvas

\section{Research}

Keywords: COVID 19, rural community, societal groups, probit model

Posted Date: August 11th, 2020

DOI: https://doi.org/10.21203/rs.3.rs-51668/v1

License: (c) (i) This work is licensed under a Creative Commons Attribution 4.0 International License.

Read Full License 


\section{Abstract}

This study assesses the rural community engagement to respond to the novel coronavirus and challenges faced, and possible factors determining their preparedness and response to the pandemic in rural Ethiopia. A total of 190 sample respondents were interviewed, and then descriptive statistics and a probit model were employed for data analysis. The result revealed that various individual and community groups practiced social work response to coronavirus, but socioeconomic and other institutional factors constrained their effectiveness and performance. The probit model regression analysis indicated that the rural households preparedness to coronavirus has influenced by gender characteristics, age category, educational level (household head \& family members), mobile ownership, extension service, participation in social groups, economic status, and income from off/non-farm activities. Thus, much more attention needs to be given by a government and other stakeholders to confront the virus and its possible effect.

\section{Introduction}

The novel coronavirus pandemic (COVID-19) outbreak emerged in Wuhan, which is the Hubei Province of China and then spread out quickly to developed and underdeveloped countries [1]. The virus resemblance to severe acute respiratory syndrome coronavirus (SARS-CoV) called "Severe Acute Respiratory Syndrome Coronavirus 2 (SARS-CoV-2)" [2]. Starting from the date of the announcement in China, coronavirus caused the death of many people, and globally COVID death surpass 650 thousand with more than 16 million cases. The virus spreads from person to person through making physical contact with an infected person (disrespecting social distance), air when an infected person sneezes, coughs, and exhales during a meeting, at a time of being together. Also, washing hands, using a mask, avoiding physical contact, and valuing social distance decreases the transmission rate [3].

Coronavirus approaches as a pressing problem of Ethiopia when the world health organization [4] reported 282 cases of coronavirus from four countries. The quick spread of the discovered virus and meaningful association of spreading methods with Ethiopian people's lifestyle fear the Ethiopian government. Before the virus reached Ethiopia, the Ethiopian airline had designed directions to undertake preventive measures to the passengers and service providers. However, Ethiopia officially reports the first coronavirus case on March 13, 2020, and had increased to 2019 cases with 27 deaths as of July 7, 2020 [5]. Following pandemic entrance, the Ethiopian government had taken numerous preventive measures including the state of emergency, partial to complete lockdown, quarantine, awareness creation, and social protection to minimize the danger of the pandemic [6, 7]. Additionally, the country has currently suspended movement both within its borders and at international boundaries to reduce the spreading of the pandemic.

Presently, the novel pandemic (COVID-19) is challenging the health, socioeconomic, and political condition of Ethiopia [8,9]. The existed preventive measures like lockdown borders, state of emergency, movement restriction, school closure, isolation, and transport restrictions challenged the socioeconomic condition of majority peoples as it cased the loss of jobs, salaries, and daily income (daily laborers), and 
it exerts adverse effects on food and nutrition security [10]. Moreover, the Ethiopian election 2020, which was legitimately suspended by the Ethiopian government, is clearly showing the existed crisis due to COVID 19. In addition, the current pandemic (COVID 19) related restriction have been influenced the rural communities, farm households, rural youths, and their families from a different perspective. It could be due to the decreased market share and lockdown measure of the informal and private business center as it employed the majority of the rural labor source in different of the country. Thus, adults and youth who usually support their family in cash and kind to strengthen their family purchasing power of agricultural inputs were currently found at home due to COVID 19 related measures. Besides, the pandemic indirectly affecting the agricultural sectors that we all depend on.

Rural Ethiopia encompasses more than $80 \%$ of the overall Ethiopian population and also the mainstay of agriculture production in the country. Despite the role of frequent hand wash, waste management, and hygienic practices to reduce the human spread of the pandemic [4], the majority of the rural area in Ethiopia is living within areas of insufficient health care centers, absent of road infrastructure; and lived in deprivation of protected water, sanitation, and hygienic conditions [11]. Besides, less accessibility to media, their relatively low socioeconomic level, and the perceived difference in demographic characteristics to that of urban influence social work response, preparedness, and response mechanisms to coronavirus. These can put a lot of pressure on the health of rural people and worry about tomorrowagricultural production and productivity that could mainly produce by smallholder farmers in the rural area. The information explained above indicates the particular importance of bringing behavioral change, encourage societal involvement, and enhancement the preparedness and responses at an individual and collective level [12].

Regardless of the recent progress, given significant current gaps in the empowerment of rural peoples and farmers in Ethiopia, the issue of the rural peoples in terms of health, agricultural production, market participation, and the alternative adaptation mechanisms to overcome these problems need more great attention [13]. Thus, the existed coronavirus prevention and response practices in the rural area are not satisfactory. However, as recommended by (Food and agricultural organization [14] ensure timely and successful preventive measures in rural populations possibly avoids the further spread of poverty and hunger. It requires a much further pronounced social work in the rural area in collaboration with responsible stallholders to prevent and reduce vulnerability. In this regard, investigation of what is being known and unknown about the virus by the rural peoples helps to make immediate intervention, and also probably enhances people's understanding.

Many of the research work on COVID 19 have targeted the socioeconomic impact of coronavirus $[4,8,12$, 14-31]. The available works on COVID 19 in Ethiopia focused on the probable impact of COVID 19 by employing desk review and experts point of view, without empirical evidence. However, in countries having poor health care centers in terms of quality and quantity to challenge the pandemic, much great work on peoples' understanding, societies' involvement, and peoples' preparedness and response through investigating gaps and making appropriate intervention are acceptable. 
Unless significant attention given to the rural area, the effect of the novel coronavirus (2019-Ncov) on the rural health and socioeconomic conditions for the majority of the agrarian-based economy dependent countries, including Ethiopia will risky after COVID-19. Thus, the health of rural peoples affects direct influence on agricultural labor sources, and also the existed agricultural value chain beside it will potentially cause the death of many peoples. Therefore, coronavirus would dangerous if not managed well. In response, this study aimed to assess the societal response of COVID 19 and factors affecting rural community preparedness and response to the novel coronavirus (2019-nCOV). The study aims to provide input for government intervention approaches to protect the current public health of rural peoples and future agricultural production as well. The study result may also provide information for future research related to this topic.

\section{Methods}

\section{Sampling procedures and participants}

The two-stage sampling procedure was applied to select sampled households. In the first stage, 51 peasant associations from the three largest administrative regions were selected by employing a purposive sampling technique. These peasant associations are chosen due to time and budget constraints, and also the availability of data collectors as well. The availability of full information for data collectors at wolkite university and the existed telegram page for each data collector ease the communication process. In the second stage, four rural households were chosen randomly from the list of household heads in their respective peasant associations. Accordingly, a total of 204 household heads (4 each from peasant associations) were used to collect the relevant information. The sample size was selected considering representativeness, budget, and the unnecessarily delay in data collection, analysis, and write up.

\section{Data collection}

Due to the case of coronavirus pandemic, the Ethiopian government in the middle of March 2020, recommended its people to avoid face-to-face dealings and movements within the domestic region. For this reason, social media (phone \& telegram interview) were used to communicate with the data collectors. The study designed structured questionnaires, which was developed based on previous researchers' outlook of COVID 19 and also the authors' experience in different rural areas of Ethiopia and then applied through the interview schedule. The questionnaire was first sent to the data collectors through their telegram page. Then, the students have suggested to print it and then administered the data collection process by applying an interview schedule with selected respondents. A post-office box was used for collecting completed questionnaires from the data collectors. The study was conducted from April 20 to May 30, 2020, and the interview schedule was undertaken by using local language for respondents who declined to speak the national language fluently.

\section{Data type and sources}


The majority of the data nature used was a qualitative type, but quantitative data were also collected. Both primary and secondary data sources were also used. Data associated with societal works and responses, demographic, socioeconomic, and institutional factors affecting the preparedness and response to COVID 19 pandemic were collected from primary sources. Secondary data were taken from Journals, and statistical bulletin reports WHO, FMOH, WFP, and FAO.

\section{Data analysis}

The STATA software version 13 was used to analyze the collected data. The qualitative data were organized and coded into quantitative form through the following scientific methods applied for analysis purposes. Then, both descriptive and econometrics model methods of analysis were used. Societies' responses to the novel coronavirus, demographic, socioeconomic, and institutional related information were described by employing descriptive statistics, namely proportion, and percentage. Besides, the probit model was used to analyze factors affecting the preparedness and response of COVID 19 in rural Ethiopia.

\section{Probit model analysis}

The study used a binary dependent variable that has two values, typically coded as 0 for households who didn't engage in any preparedness and response strategy to COVD-19. The dependent variable is linearly related to a set of independent variable $x$ and a disturbance term (e). The link between the observed variable and the latent $y *$ is made with simple measurement equation:

$$
y_{i}=\left\{\begin{array}{l}
1 \text { if } y_{i} *>0, \\
0 \text { if } y_{i} * \leq 0
\end{array}\right.
$$

Cases with a positive value of $y^{*}$ are observed as $y=1$, while cases with negative or zero value of $y^{*}$ as $y$ $=0$. Accordingly, the surveyed respondents were asked if they made a behavioral change for either the preparedness or response to COVID 19 or not. Respondents differ in their opinion on the issue, and some respondents very adamantly agree with the adaption of behavioral change but, some very adamantly disagree, and others have only weak looks one way or on the others.

The probit model estimated by the maximum likelihood estimation techniques and the log-likelihood function for the probit model is specified as follows:

$$
\operatorname{Ln} \operatorname{Li}(\beta)=y i \log \left\{\phi\left(x_{i} \beta\right)\right\}+\left(1-y_{i}\right) \log \left\{1-\phi\left(y_{i} \beta\right)\right\}
$$

Following the analyses, the probit model is adopted as:

$$
\operatorname{Pr}\left(y_{i}^{*}>0 \mid x_{i}\right)=\phi\left(x_{i} \beta\right)
$$


where $\Phi$ is the standard cumulative normal distribution function with variance one and numerically maximized concerning $\beta$. The predicted probability for any set of values of independent variables can be computed by using a verity of commands in STATA. Independent variables used for this study are presented in Table 1.

Table 1

Description of explanatory variables used in the probit model

\begin{tabular}{|ll|}
\hline Variable & Description and measurement \\
\hline Sex & A dummy variable with value 1 for males and 0 for females \\
Age & $\begin{array}{l}\text { A categorical variable indicating the age interval of households with value } 1 \\
\text { for those aged } 18-35,2 \text { for aged } 35-55,3 \text { for those who are aged } 55 \text { or above }\end{array}$ \\
Marital status & $\begin{array}{l}\text { A dummy variable for the marital status of respondents with value } 0 \text { for } \\
\text { divorced/single/ widowed/widower, } 1 \text { for married }\end{array}$
\end{tabular}

Educational level A categorical variable for the educational level of a household head with value of a household $\quad 0$ for illiterate, 1 for primary educational level, 2 for secondary level head

Family situation A dummy variable for the household situation with value 1 for households with children for more than 10 years, 0 for households without children/those whose children less than 10 years

Educational level of children aged above 10 years

Ownership of mobile

Ownership of radio

Engagement in community groups

Extension information

Off/non-farm income

Households economic stats in the locality

Households support from others
A maximum educational level of children in a household with value 0 illiterate, 1 for primary, 2 for primary level, 3 secondary levels, 4 for college/university level and others

A dummy variable with value 1 if any of a households member have mobile, 0 otherwise

A dummy variable with value 1 if any of a households member have a radio, 0 otherwise

A dummy variable with value 1 if a household has social community engagement; 0 otherwise

A dummy variable with value 1 if a household received formal extension information about COVID 19; 0 otherwise

A dummy variable with value 1 if a household received off/non-farm income; 0 otherwise

A dummy variable with value 1 if relatively good economic status; 0 otherwise

A dummy variable with value 1 if they have options to receive support from their child/relatives/or other; 0 otherwise

\section{Results}




\section{Characteristics of sampled respondents}

Table 2 presents a description of the variables used in the analysis. The sample respondents were about 204 households from the three largest administrative regions of Ethiopia. However, about 14 sampled respondents excluded from analyses as we failed from collecting the data. As shown in Table 2, the majority (69.4\%) of the households were male-headed. Most of the household heads interviewed (72.6\%) were married. Concerning the age category of the respondents, about $42.1 \%$ were adults, $40.5 \%$ were elder while the remaining about $17.4 \%$ were in the Youngers. In terms of education status, about $15.3 \%, 17.9 \%$, and $8.4 \%$ attended primary, high school, and preparatory levels of education, respectively. The remaining $58.4 \%$ of the respondents were illiterate. Currently, about $85.6 \%$ were had family members (children) aged above 10 years while about $14.7 \%$ were had not children at all or aged 10 years.

Regarding mobile and radio ownership, about $54.2 \%$ of the households owned mobile phones, and about $31.1 \%$ of households owned and used radio for information. With respect to respondents' participation in social community groups participation either culturally or religiously and other communal labor share groups, about $58.4 \%$ participated in the time COVID 19. Also, more than $59 \%$ of the sample respondents reported the absence extension service related to COVID 19. Furthermore, about $37.4 \%$ of the respondents engaged in off-farming activities like a daily laborer, petty-trading, and craftsmanship to secure family needs; and close to $34.2 \%$ of the respondents received support from others to carry their normal lifestyles (Table 2).

The study result presented in Table 2 also depicted the demographic, socioeconomic, and institutional differences among respondents who actively engaged in preparedness to COVID 19, and respondents who rejected it. Among households participated in responding to COVID 19, about $25.3 \%$ were males, $35.3 \%$ were married, $29.5 \%$ were under the adult age category, $17.9 \%$ household heads were illiterate, and $38.4 \%$ had family members aged above 10 years. Regarding the educational level of other family members (aged above 10 years), about $6.8 \%$ of respondents were illiterate, $13.6 \%$ were at the primary school level, $13.6 \%$ were secondary school level, $2.6 \%$ were at a preparatory school level, and $9.5 \%$ were at college and university levels. Furthermore, about $36.3 \%$ of households had mobile, about $12.1 \%$ of had a radio, about $30.5 \%$ of the respondents were participated in the social community group activities, about $26.3 \%$ of the respondents received extension information from formal sources. Considering the economic status, the majority (32.6\%) were at the medium economic level, $28.4 \%$ of them engaged in off and nonfarm activities and closely $18.4 \%$ of those households were received support from others to carry on their usual lifestyle (Table 2). 
Table 2

Demographic characteristics of sample respondents

\begin{tabular}{|c|c|c|c|c|}
\hline \multirow[t]{2}{*}{ Variable } & \multirow[t]{2}{*}{$\begin{array}{l}N= \\
190\end{array}$} & \multirow[t]{2}{*}{ Proportion } & \multicolumn{2}{|c|}{$\begin{array}{l}\text { Preparedness and response to COVID } \\
19\end{array}$} \\
\hline & & & Yes & No \\
\hline \multicolumn{5}{|l|}{ Sex } \\
\hline Male & 130 & 0.694 & 0.253 & 0.432 \\
\hline Female & 60 & 0.316 & 0.211 & 0.105 \\
\hline \multicolumn{5}{|l|}{ Marital status } \\
\hline Married & 138 & 0.726 & 0.353 & 0.374 \\
\hline $\begin{array}{l}\text { Single/ } \\
\text { widower/divorced/widowed/ }\end{array}$ & 52 & 0.274 & 0.111 & 0.163 \\
\hline \multicolumn{5}{|l|}{ Age groups } \\
\hline 18-35(young) & 33 & 0.116 & 0.063 & 0.053 \\
\hline $35-55$ (adult) & 80 & 0.421 & 0.295 & 0.158 \\
\hline$>55$ (elder) & 77 & 0.405 & 0.105 & 0.326 \\
\hline \multicolumn{5}{|l|}{ Education level household head } \\
\hline illiterate & 111 & 0.584 & 0.179 & 0.405 \\
\hline Primary level & 29 & 0.153 & 0.111 & 0.042 \\
\hline High school & 34 & 0.179 & 0.105 & 0.074 \\
\hline Preparatory & 16 & 0.084 & 0.068 & 0.016 \\
\hline \multicolumn{5}{|l|}{$\begin{array}{l}\text { Family members aged above } \\
10 \text { years }\end{array}$} \\
\hline Yes & 162 & 0.856 & 0.384 & 0.468 \\
\hline No & 28 & 0.147 & 0.079 & 0.068 \\
\hline \multicolumn{5}{|l|}{$\begin{array}{l}\text { Educational level of family } \\
\text { members }\end{array}$} \\
\hline Illiterate/children aged $<10$ & 25 & 0.132 & 0.063 & 0.068 \\
\hline Primary school & 111 & 0.584 & 0.21 & 0.374 \\
\hline High school & 25 & 0.132 & 0.063 & 0.068 \\
\hline Preparatory school & 6 & 0.032 & 0.026 & 0.005 \\
\hline University /college & 23 & 0.121 & 0.095 & 0.026 \\
\hline
\end{tabular}




\begin{tabular}{|c|c|c|c|}
\hline Variable & $\begin{array}{l}N= \\
190\end{array}$ & Proportion & $\begin{array}{l}\text { Preparedness and response to COVID } \\
19\end{array}$ \\
\hline \multicolumn{4}{|c|}{ Ownership of active mobile phone } \\
\hline Yes & 103 & 0.542 & 0.179 \\
\hline No & 87 & 0.458 & 0.358 \\
\hline \multicolumn{4}{|c|}{ Ownership of radio } \\
\hline Yes & 59 & 0.311 & 0.189 \\
\hline No & 131 & 0.689 & 0.347 \\
\hline \multicolumn{4}{|c|}{$\begin{array}{l}\text { Social community groups } \\
\text { participation }\end{array}$} \\
\hline Yes & 111 & 0.584 & 0.279 \\
\hline No & 79 & 0.416 & 0.258 \\
\hline \multicolumn{4}{|c|}{ Formal extension about COVID 19} \\
\hline Yes & 77 & 0.405 & 0.142 \\
\hline No & 113 & 0.595 & 0.395 \\
\hline \multicolumn{4}{|c|}{ Off/non-farm income households } \\
\hline Yes & 71 & 0.374 & 0.089 \\
\hline No & 119 & 0.625 & 0.447 \\
\hline \multicolumn{4}{|c|}{ Relative households economic stats } \\
\hline Poor & 80 & 0.421 & 0.321 \\
\hline Medium & 89 & 0.468 & 0.142 \\
\hline Good/better & 21 & 0.111 & 0.074 \\
\hline \multicolumn{4}{|c|}{ Households support from others } \\
\hline Yes & 65 & 0.342 & 0.158 \\
\hline No & 125 & 0.658 & 0.379 \\
\hline
\end{tabular}

\section{Cognizant of coronavirus and related challenges}

The survey of rural households' understanding of coronavirus pandemic showed that the majority of rural households' had not an understanding of the virus prevention, spread, and response mechanisms, despite the information of the outbreak. Based on the result, only about $25.5 \%$ of the surveyed respondents had information about the prevention methods, about $38.40 \%$ of the respondents had information on the 
spreading ways, and also $18.58 \%$ of the respondents had understood on the alternative adaptation methods to reduce health and socio-economic effect of COVID 19. In this regard, currently close to $46.4 \%$ of the respondents practiced prevention methods by avoiding close contact, washing hands with water and soap, and avoid handshake to reduce the spread of the virus and its adverse effect. Surprisingly, the result revealed the existence of peoples who practiced prevention methods without adequate information about the potential benefit from it. Thus, about $20.9 \%$ of the respondents practiced the prevention methods temporarily when they observed others to do so (Table 3 ).

Despite recent progress, the result of the study showed a low level of awareness of COVID 19 by the majority in rural peoples of Ethiopia. In this respect, the study identified six challenges that caused the lower-level of understanding of coronavirus. Firstly, limited/absent of formal extension information about COVID 19 by the Ethiopian government, religious center, or other stakeholders. Accordingly, about $59.5 \%$ of the surveyed respondents revealed the absence of a formal extension source about COVID 19 in their respective localities. Secondly, limited social media accesses and alternatives in the rural areas caused less information access for the majority. Limited use and ownership of social media like mobile, smartphones, radio, and other social media enlarge the information gap in the rural peoples of Ethiopia. Thus, about $68.59 \%$ and $45.8 \%$ of the respondents have not owned phones and radio, respectively at household levels (Table 2). Thirdly, the tough season for agricultural farming when the pandemic has reached Ethiopia decreased the possible information sharing opportunities among different stakeholders in their respective locality. In this regard, the majority (74.35\%) of the respondents revealed that as they gave much more focus on agricultural production than COVID 19. The fourth challenge is directly associated with public infrastructure (inadequacy and poor quality for roads), and also health care centers (clinics) for making close contact with the majority of rural peoples by other external stakeholders associated with COVID 19. The limited number of health extension services also challenges health accessibility. In this respect, about $37.6 \%$ of the respondents revealed the unavailability of public roads close to their villages.

The fifth challenge is related to the raining season (summer) caused by the breakdown of road, flooding, and crossing of larger rivers are impossible. It decreased the existed direct contact between the governments and its peoples, and also among the peoples themselves. It decreases the information dissemination process within and between different rural areas. Concerning this, about $48.9 \%$ of the respondents have challenged by this problem so far. Lastly, the dispersed nature of residents homes of in the rural area also constrained the information provision system for health extension service providers and in this regard almost close to $61.5 \%$ of the respondents revealed the unhappiness' of the health extension workers in the time other health services in their locality (Table 3). 
Table 3

Rural peoples cognizant of coronavirus and challenges in the time of COVID 19

\begin{tabular}{|lll|}
\hline Rural peoples in the time of COVID 19 and/or challenges & N & Proportion \\
\hline Adequate information on prevention (yes) & 48 & 0.255 \\
\hline Adequate information on spreading methods (yes) & 73 & 0.384 \\
\hline Adequate information on response methods (yes) & 35 & 0.186 \\
\hline Practiced prevention and response (yes) & 88 & 0.464 \\
\hline Declined focusing from COVID 19 due to agricultural farming (yes) & 142 & 0.744 \\
\hline Constrained by public infrastructure (road, health) (yes) & 75 & 0.376 \\
\hline Constrained by the breakdown of infrastructure due rainy season (yes) & 93 & 0.489 \\
\hline Feedback from health and other extension related to residents house (not good) & 117 & 0.615 \\
\hline
\end{tabular}

\section{Social work responses to COVID 19}

As stated by [32], successful control of the novel coronavirus (COVID 19) requires interactive social work response. In this respect, the study result on the existed societal works so far, and accordingly, about $66.45 \%$ of the respondents revealed the absence of influential societal movement in their respective locality. The remaining $43.55 \%$ of the respondents showed the available few youths (university \& preparatory students), religious leaders, community leaders, agricultural extension service providers, supervisor of road transport and traffic police, and also the input providers (farmers cooperatives and unions). Thus, about $35.8 \%$ of the respondents acknowledged the students' effort to enhance the community conciseness to COVID 19. Nevertheless, their engagement was limited to awareness creation only rather than mobilizing peoples by preparing hand wash programs, enhance peoples to use masks through incentives due to socio-economic, and institutional constraints.

The societal religious-based monthly anniversary practiced by orthodox Christianity followers in the rural area are among the communal association that creates suitable conditions for the spread of the virus. To reduce the local religious leaders placed restriction and accordingly, about $21.57 \%$ of the respondents revealed the presence of restriction mahiber, about $47.06 \%$ of the respondents revealed partial restriction on iquib, and also about $25.49 \%$ of the respondents confirmed the availability of partial restriction on idirr and tezkar in their locality. Debo and wonfel, which is labor-mobilizing techniques for those households who have cultivated land or small family size, are used for sharing labor for agricultural production. Local communities' leaders play a significant role in preventing coronavirus by imposing restrictions and therefore, about $58.86 \%$ of the respondents revealed the restriction on debo and wonfel, about $35.29 \%$ of the respondents confirmed partial restrictions on the wedding anniversary (Table 4).

Agricultural extension service providers are among the societal groups that are actively involved in advising rural households about the alternative means of agricultural production in the time of COVID 19 
in rural Ethiopia. Consequently, about $33.5 \%$ of the respondents revealed the positive contribution of the rural kebeles development agents to facilitate agricultural farming, despite significant attention is also given to the pandemic. Agricultural cooperatives and its unions, who are a potential provider of agricultural inputs, are actively participated in preventing and reducing the spread out of the virus, and also to secure future agricultural production. Close to $43.65 \%$ of the respondents agreed with the positive contribution of agricultural input distributors by lecturing about social distancing in the time of input provision and also by reducing the unnecessarily delay of input provided to farmers in the time of COVID 19. In line with the partial restriction on public transport, supervisors, and traffic police also play a significant role in preventing the spread of the virus, and about $35.9 \%$ of the respondents confirmed the effective and responsible duty of public transport supervisors and traffic police in their respective locality (Table 4).

Table 4

Rural community engagement to prevent/reduce coronavirus

\begin{tabular}{|c|c|c|}
\hline Degree of social work response & $\mathbf{N}$ & Proportion \\
\hline University and preparatory level of students engagement (yes) & 68 & 0.358 \\
\hline \multicolumn{3}{|l|}{ Religious leaders and elders engagement(yes) } \\
\hline Imposed restriction on Mihber & 49 & 0.256 \\
\hline Imposed restriction on Equib & 77 & 0.406 \\
\hline Imposed restriction on Idirr and tezikar & 48 & 0.25 \\
\hline \multicolumn{3}{|l|}{ Local community leaders and other stakeholders (yes) } \\
\hline Debo and wonfel & 106 & 0.558 \\
\hline Wedding anniversary & 67 & 0.353 \\
\hline $\begin{array}{l}\text { Multiple support agricultural extension service providers about COVID } 19 \text { and } \\
\text { agricultural production as well (yes) }\end{array}$ & 71 & 0.376 \\
\hline $\begin{array}{l}\text { Agricultural input providers namely agricultural cooperatives and unions } \\
\text { engagement (yes) }\end{array}$ & 83 & 0.436 \\
\hline Public transport supervisors and traffic police engagement (yes) & 68 & 0.359 \\
\hline
\end{tabular}

Tables 1 and 2 depict the descriptive and summary of explanatory variables used in the probit models, respectively. Based on the result that about $46.4 \%$ of the respondents have participated in preparedness and response to COVID 19. The model was checked for the suitability and explanatory power of independent variables over the dependent variables. The test results indicated the likelihood function of the probit model was significant (Wald $\chi 2=84.36$ with $P<0.001$ ), showing its explanatory power. The results of the probit model are presented in Tables 5 , and some of the explanatory variables and their respective marginal values are statistically significant in determining households' preparedness and 
response to COVID 19 as expected. The marginal effects of the result indicated the changes in the probability of rural society in preparedness and response to COVID 19 for a change in the explanatory variable.

The marginal effects of significant explanatory variables are used in estimating the likelihood of preparedness and response to COVID 19. The marginal effect for sex of household head showed that male household head decreases the probability of enhancing and engaging in preparedness and response to COVID 19 by $29 \%$ as compared to female household heads. Compared to younger household heads, adult household heads have a $33 \%$ higher probability of engaging in the preparedness and response to coronavirus but, the elder household heads have a $31 \%$ lesser probability of engagement. Households who attended the preparatory level of education have a $41 \%$ higher probability of engaging in preparedness and response to COVID 19 as compared to the illiterate one. Besides, households who have a mobile phone have a $52 \%$ higher probability of engaging COVID 19 preparedness and response compared with households survived without phones (Table 5).

Furthermore, compared to their counterparts, households received extension information about COVID 19 extension information, social community groups' participants, and income from off/non-farm activities have $25 \%, 34 \%$, and $26 \%$ higher probability of engagement in preparedness to the novel coronavirus. Also, compared to households without family who attended formal education, households with family members attended preparatory education levels have a $59 \%$ higher probability of engaging in preparedness and response to combat coronavirus. Besides, households who belong to middle economic status have a $32 \%$ higher probability of making preparedness and response compared to the lowest economic group households. 
Table 5

The probit regression analysis of factors affecting the preparedness and response to CIVID 19 in rural Ethiopia.

\begin{tabular}{|c|c|c|c|c|}
\hline \multirow[t]{2}{*}{ Explanatory variable } & \multicolumn{2}{|l|}{ Regression } & \multicolumn{2}{|c|}{ Marginal effect } \\
\hline & Coefficient & $\begin{array}{l}\text { Robust Std } \\
\text {.Err }\end{array}$ & Coefficient & $\begin{array}{l}\text { Std. } \\
\text { Err }\end{array}$ \\
\hline Constant & -2.272 & 0.552 & - & - \\
\hline Sex of HH (female) ${ }^{a}$ & $-0.75^{\star \star}$ & 0.311 & $-0.29 \star \star \star$ & 0.115 \\
\hline \multicolumn{5}{|l|}{ Age category (young)a } \\
\hline Adult age group & $0.85^{\star \star}$ & 0.433 & $0.33^{\star \star}$ & 0.158 \\
\hline Elder age group & $-0.81^{\star}$ & 0.472 & $-0.31^{*}$ & 0.166 \\
\hline $\begin{array}{l}\text { Marital status of HH (single, divorced, } \\
\text { widowed) }{ }^{\mathrm{a}}\end{array}$ & 0.32 & 0.278 & 0.13 & 0.106 \\
\hline $\begin{array}{l}\text { Household member above } 10 \text { years (not } \\
\text { have) }{ }^{\mathrm{a}}\end{array}$ & -0.18 & 0.779 & -0.07 & 0.310 \\
\hline \multicolumn{5}{|l|}{ Educational level of $\mathrm{HH}(\text { illiterate })^{\mathrm{a}}$} \\
\hline Education level of HH (primary) & 0.42 & 0.408 & 0.16 & 0.159 \\
\hline Education level of $\mathrm{HH}$ (high school) & 0.16 & 0.418 & 0.06 & 0.166 \\
\hline Education level of $\mathrm{HH}$ (preparatory) & $1.15^{\star \star}$ & 0.553 & $0.41^{\star \star \star}$ & 0.154 \\
\hline Mobile ownership in a household (not owned) ${ }^{a}$ & $1.52 * \star \star$ & 0.305 & 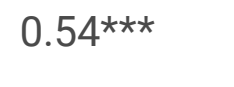 & 0.086 \\
\hline Radio ownership in a household (not owned) ${ }^{a}$ & -0.09 & 0.312 & -0.03 & 0.122 \\
\hline $\begin{array}{l}\text { Extension service about COVID } 19 \text { (not } \\
\text { received) }{ }^{a}\end{array}$ & $0.63^{\star \star}$ & 0.298 & $0.25^{\star \star}$ & 0.114 \\
\hline \multicolumn{5}{|l|}{ Education level of families (illiterate) ${ }^{a}$} \\
\hline Education level of families (primary) & -0.07 & 0.683 & 0.03 & 0.269 \\
\hline Education level of families (high school) & 0.38 & 0.785 & 0.15 & 0.308 \\
\hline Education level of families (preparatory) & $2.87 \star \star \star$ & 1.108 & $0.59 \star \star \star$ & 0.063 \\
\hline Education level of families (university/college) & 0.96 & 0.817 & 0.36 & 0.264 \\
\hline Social group participation(not participated) ${ }^{a}$ & 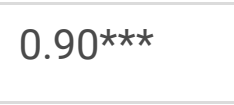 & 0.294 & $0.34^{\star \star \star}$ & 0.101 \\
\hline \multicolumn{5}{|l|}{ Relative economic status (poor) ${ }^{a}$} \\
\hline Medium & $0.83^{*}$ & 0.322 & $0.32^{\star * \star}$ & 0.117 \\
\hline
\end{tabular}




\begin{tabular}{|llllr|}
\hline Explanatory variable & Regression & & \multicolumn{2}{l|}{ Marginal effect } \\
\hline Good/better & -0.41 & 0.51 & -0.15 & 0.181 \\
\hline Off/non-farm income (did not have) & $0.69 \star *$ & 0.309 & $0.26^{\star \star}$ & 0.117 \\
$\begin{array}{l}\text { Households economic support from others } \\
\text { (No) }\end{array}$ & 0.03 & 0.322 & 0.12 & 0.127 \\
\hline
\end{tabular}

\section{Discussion}

Improving the rural societies understanding of COVID 19 is vital for safeguarding the health and livelihoods of the most vulnerable people, including Ethiopia. Hence, the majority of rural households are from low socioeconomic groups that probably exposed to adverse conditions, such as financial, food, and medicine safety problems [25]. In line with this, this study surveyed the rural peoples' consciousness of coronavirus and possible factors hindering their preparedness and response. The result revealed the low-level cognizant and insufficient attention to coronavirus. The level of community engagement to reduce the vulnerability is still at the infant stage, and the majority of the rural peoples behave in a usual manner before the outbreak of novel coronavirus (2019-nCOV).

The result of the study presented in Table 3 indicates that only a few of the respondents understand the transmission, prevention, and way of confronting its effect, and then engage in changing their social behavior to minimize the possible consequences. Thus, the pandemic requires organized communitybased prevention and response rather than a few engagements. Rural household health, agricultural production, and food security condition would expand and hinders the country's strategic objective of reducing food security problems and increasing agricultural production levels. The world health organization recommends individuals to quarantine or to trips to areas where a large number of peoples probably exist. In this respect, social and communal association groups of either religiously or culturally practiced in Ethiopia create suitable conditions for COVID 19. The result presented in Table 3 shows the availability partial and complete restriction on communal association stetted by religious leaders, elders, and local administer but, the absence of any formal measures majority of the peoples have practiced it. It could be due to the unavailability of legitimacy coverage in the restriction by the religious center. However, different socio-economic and institutional factors affect rural peoples' preparedness and the response of COVID 19. Besides, respondents also revealed the existence of peoples' criticized the restriction by believing GOD will save me narratives.

The probit model regression analysis was employed to identify factors affecting the preparedness and response to COVID 19 in rural Ethiopia. The marginal effects of the probit regression analysis presented in Table 2 showed that the age of household head, educational level of a household head, ownership mobile phone within a household, access to formal extension information, educational level of household members, social group participation, households economic situation, and income from off/non-farm activities have a positive and significant effect on the rural households preparedness and response to novel coronavirus (2019-nCOV) while the sex of a household head affects negatively. This difference 
among rural communities calls further intervention to facilitate the prospect of enhanced rural households preparedness and response to COVID 19.

Based on the results, male-headed households' are less likely to engage in preparedness and response to novel coronavirus compared to female household heads. It could be due to the more attentiveness of females to practices actions by others or could link to perspicacious characteristics compared to males. On the other hand, males might not fear and not provide match emphasis on the information due to the natural character compared to females. As expected, the age category of a household head is significantly associated with households' preparedness and response to confront coronavirus pandemic. Compared to young household heads, household heads within the adult age category are more likely to engage in preparedness and response to confront coronavirus but, the elder household heads are less likely to engage in preparedness and response activities. It could be associated with the adult age category is the stage where the majority of peoples coming relatively wise for the sake of others, including families. This suggesting that adult headed households better recognizing the risks associated with the novel coronavirus (2019-nCOV). On the other hand, elder households' heads are not disturbed by the outbreak of the new pandemic as they experienced many indigenous and global diseases so far. Besides, elders believed that GOD saves our lives rather than engaging in preparedness and response COVID 19.

Ownership of mobile phones within the household level is positively and significantly related to household preparedness and response to coronavirus. The result showed that households who own mobile phones in their families are more likely prepared to prevent and respond to the pandemic. This can be associated with the fact that the Ethiopian telecommunication office provides extension information about COVID 19 instead of a ring voice of the caller before it reached the receiver. Households who did not own mobile phones have relatively less access to real information, and this decreases the probability of engagement in preparedness and response to coronavirus.

The extension service provided to COVID 19 by the Ethiopian government or religious centers is the only trusted and accepted information sources in almost all parents rural Ethiopia. Those respondents who received extension information about COVID from above-listed sources could have a better understanding of prevention, transmission, and response mechanisms, and therefore, more likely to engage in preparedness and response to the virus. The result also suggests households who received extension information tend to use their family labor and other technology packages instead of shared labor to practices agricultural production.

The education level of the families/children identified as a significant factor for preparedness and response to COVID 19, and households with family members attended preparatory or university level education are more likely to engage in preparedness and response to novel coronavirus. It could be due to the students who have actively attended preparatory and university level education are matured and acceptable in their family, and this could help the family to have a full understanding of the pandemic. Besides, the majority of them owned mobile phones smart either phone or others for information, and this 
helps them to get updated information from either internet or phone call for sharing with their family. Moreover, households who currently participated in social community groups are more likely to prepare and respond to coronavirus as they received information about these community group members.

Compared to the poor (lower economic level), households with a medium economic level are more likely to engage in coronavirus preparedness and response. The preparedness and response mechanisms of COVID 19 require additional costs, and those who afford such costs for hygienic, sanitary, and others could engage in the adaptive response of COVID 19. Moreover, compared to their counterpart, households who had off/non-farm income are more likely to engage in preparedness and response to COVID 19. It could be the nature of off /non-farm activities, the potential information accesses about the pandemic, and the income from non-farm sources may probably determine their engagement.

\section{Conclusion}

This study investigated factors affecting rural people's preparedness and response to the novel coronavirus (2019-nCOV). The study employed the probit model to explore the determinants of rural households' preparedness and response to coronavirus. The rural parts of Ethiopia were wrongly expected to be advantageous and easily accessed information about COVID 19 due to the homecoming of the educated youths from cities, small towns, university and also students can access social media. However, as is evidenced by the results of this study, the majority of the study site has challenged by the availability full and real information gap, inadequate, and ineffective, infant, and not well-organized social response mechanisms due to socioeconomic and institutional constraints.

The result of the study showed that the rural households' preparedness and response to the novel pandemic are affected by demographic, institutional, and socioeconomic factors. The majority of the significant variables (ownership of mobile phones, access to formal extension information, educational level of household members, social group participation) determining rural peoples' preparedness and response in this study came from the information gap on the novel coronavirus (2019-nCOV). On the other hand, the majority of rural households are existed in the low economic groups and challenged by cash income sources, and cannot afford to buy the prevention equipment of COVID 19. Thus, more attention needs to give for the rural community in term of awareness by using technical language and

local language; temporary support (sanitary equipment and cash) to these more vulnerable groups as an incentive enhance peoples to apply prevention and response methods of coronavirus in rural Ethiopia.

For future research, it is recommended to check the government's actions and their impacts to face COVID 19, especially public policies aimed at the rural population of Ethiopia.

\section{Declarations}

\section{Acknowledgements}

Authors gratefully acknowledge the support and kind commitment of data collectors. 


\section{Authors' contributions}

Yonnas Addis conceived the idea. Dubale Abate contributed in collecting and analyzing the data. Both Yonnas Addis and Dubale Abate performed the interpretation of the data and wrote the manuscript. João Batista Ferreira carried out the language editing of the manuscript. The author(s) read and approved the final manuscript.

\section{Funding}

No funding was available/used for this study.

\section{Availability of data and materials}

The data used in this this study are available from the corresponding author upon reasonable request.

\section{Ethics approval and consent to participate}

Not applicable for this study.

\section{Consent for publication}

Not applicable.

\section{Competing interests}

Authors declare no competing interest.

\section{Author details}

Yonnas Addis is an MSc degree in Agribusiness and Value Chain Management. A lecturer and researcher at wolkite university, Ethiopia. Head, department of ABVM at Wolkite University. Yonnas's main research interests are in the areas of agricultural value chains development and socio-economic development in rural area. He has published several works in the field of agribusiness.

João Batista Ferreira is a professor at the Cerrado Patrocínio University Center - UNICERP, Brazil. PhD in Business Administration from the Federal University of Lavras / MG, Brazil. Ferreira's main research interests are in the areas of agricultural production systems, marketing and markets. He has published several works in the field of administration.

Dubale Abate is a MSc degree in Agribusiness and Value Chain Management. A lecturer and researcher at wolkite university, Ethiopia.

\section{References}


1. Haider N, Yavlinsky A, Simons D, Osman AY, Ntoumi F, Zumla A, Kock R. (2020). Passengers' destinations from China: low risk of Novel Coronavirus (2019-nCoV) transmission into Africa and South America. Epidemiol Infect 148, e41, 1 - 7. https://doi.org/10.1017/S0950268820000424.

2. Gorbalenya AE, Baker SC, Baric R, Groot RJD, Drosten C, Gulyaeva AA, ... Penzar D. (2020). Severe acute respiratory syndrome-related coronavirus: The species and its viruses-a statement of the Coronavirus Study Group. doi: https://doi.org/10.1101/2020.02.07.937862.

3. World Health Organization. (2020b). Coronavirus disease 2019 (COVID-19) situation report - 91. https://www.who.int/docs/default-source/coronaviruse/situation-reports/20200420-sitrep-91-covid.

4. World Health Organization. (2020a). Novel coronavirus disease (2019-nCoV) situation report - 1. https://www.who.int/docs/default-source/coronaviruses/situation-reports/20200121-sitrep-1-2019.

5. FMOH. (2020). National comprehensive covid19 management handbook. https://www.ephi.gov.et.

6. Baye K. (2020). COVID-19 prevention measures in Ethiopia: Current realities and prospects (No. 142). International Food Policy Research Institute (IFPRI). https://www.ifpri.org/cdmref/p15738coll2/id/133729/filename/133940.pdf.

7. Abera N, Alemayehu A, Belayneh F, Jember D. (2020). Ethiopia COVID-19 Snapshot MOnitoring (COSMO Ethiopia): Monitoring knowledge, risk perceptions, preventive behaviors, and public trust in the current coronavirus outbreak in Ethiopia.

8. Badu K, Thorn JP, Goonoo N, Dukhi N, Sylverken AA. Africa's response to the COVID-19 pandemic: A review of the nature of the virus, impacts and implications for preparedness. AAS Open Research. 2020;3:19. https://doi.org/10.12688/aasopenres.13060.1.

9. Gilbert M, Pullano G, Pinotti F, Valdano E, Poletto C, Boëlle PY, Gutierrez B. Preparedness and vulnerability of African countries against importations of COVID-19: a modelling study. The Lancet. 2020;395(10227):871-7. doi:https://doi.org/10.1016/S01406736(20)30411-6.

10. Coibion O, Gorodnichenko Y, Weber M. (2020). Labor markets during the covid-19 crisis: A preliminary view (No. w27017). National Bureau of Economic Research. http://hdl.handle.net/10419/216634.

11. Adhikari, S. P., Meng, S., Wu, Y. J., Mao, Y. P., Ye, R. X., Wang, Q. Z., ... Zhou,H. (2020). Epidemiology, causes, clinical manifestation and diagnosis, prevention and control of coronavirus disease (COVID19) during the early outbreak period: a scoping review. Infectious diseases of poverty, 9(1), 1-12. https://doi.org/10.1186/s40249-020-00646-x.

12. Liu W, Zhang Q, Chen J, Xiang R, Song H, Shu S, Wu P. Detection of Covid-19 in children in early January 2020 in Wuhan, China. N Engl J Med. 2020;382(14):1370-1.

13. CEPR. (2020, May 19). Economics in the Time of COVID-19.

14. FAO. (2020, April 8). Social protection and COVID-19 response in rural areas.

15. 10.1073 /pnas.2004999117

Forster P, Forster L, Renfrew C, Forster M. (2020). Phylogenetic network analysis of SARS-CoV-2 genomes. Proceedings of the National Academy of Sciences, 117(17), 9241-9243. doi: https://doi.org/10.1073/pnas.2004999117. 
16. Hui DS, Azhar El, Madani TA, Ntoumi F, Kock R, Dar O, Zumla A. The continuing 2019-nCoV epidemic threat of novel coronaviruses to global health-the latest 2019 novel coronavirus outbreak in Wuhan, China. International Journal of Infectious Diseases. 2020;91:264-6.

17. Lau H, Khosrawipour V, Kocbach P, Mikolajczyk A, Ichii H, Zacharksi M, Khosrawipour T. The association between international and domestic air traffic and the coronavirus (COVID-19) outbreak. Journal of Microbiology Immunology Infection. 2020;53:467-72. doi:https://doi.org/10.1016/j.jmii.2020.03.026.

18. Ivanov D, Das A. Coronavirus (COVID-19/SARS-CoV-2) and supply chain resilience: A research note. International Journal of Integrated Supply Management. 2020;13(1):90-102. doi:10.1504/IJISM.2020.107780.

19. ECA. (2020, March 13). Economic Impact of the COVID-19 on Africa. .

20. Evans O. Socio-economic impacts of novel coronavirus: The policy solutions. BizEcons Quarterly. 2020;7:3-12. http://bequarterly.rysearch.com/wp-content/uploads policy-solutions.pdf.

21. UN. (2020). Socio economic impact of COVID 19 in Ethiopia.

22. World Food Programme gears up to support children left without meals due to COVID-19 school closures.

WFP. (2020, April 6). World Food Programme gears up to support children left without meals due to COVID-19 school closures.https://www.wfp.org/news/world-foodprogramme-gears-support-childrenleft-without-meals-due-covid-19-school-closures.

23. Harapan H, Itoh N, Yufika A, Winardi W, Keam S, Te H, Mudatsir M. (2020). Coronavirus disease 2019 (COVID-19): A literature review. Journal of Infection and Public Health, 13(2020)667-673.

24. Francisco O, Michael Orsini. Governing COVID-19 without government in Brazil: Ignorance, neoliberal authoritarianism, and the collapse of public health leadership. Global Public Health. 2020. doi:10.1080/17441692.2020.1795223.

25. Abdulkadir H, Tolga S, Bülent D. (2020). Adaptation and evaluation of Turkish version of the fear of COVID-19 Scale, Death Studies, 1-9. doi:10.1080/07481187.2020.1773026.

26. Young BE, Ong SWX, Kalimuddin S, Low JG, Tan SY, Loh J, Lau SK. Epidemiologic features and clinical course of patients infected with SARS-CoV-2 in Singapore. Jama. 2020;323(15):1488-94.

27. Gunthe SS, Patra SS. Impact of international travel dynamics on domestic spread of 2019-nCoV in India: origin-based risk assessment in importation of infected travelers. Globalization Health. 2020;16:1-7. doi:https://doi.org/10.1186/s12992-020-00575-2.

28. Jiang F, Deng L, Zhang L, Cai Y, Cheung CW, Xia Z. (2020). Review of the clinical characteristics of coronavirus disease 2019 (COVID-19). J Gen Intern Med, 1-5. doi: DOI:10.1007/s11606-020-05762W.

29. Li Q, Guan X, Wu P, Wang X, Zhou L, Tong Y, Xing X. Early transmission dynamics in Wuhan, China, of novel coronavirus-infected pneumonia. N Engl J Med. 2020;382(13):1199-207. https://doi.org/10.1056/NEJMoa2001316. 
30. Richardson S, Hirsch JS, Narasimhan M, Crawford JM, McGinn T, Davidson KW. Presenting characteristics, comorbidities, and outcomes among 5700 patients hospitalized with COVID-19 in the New York City area. JAMA. 2020. https://doi.org/10.1001/jama.2020.6775.

31. Holshue ML, DeBolt C, Lindquist S, Lofy KH, Wiesman J, Bruce H, et al. First case of 2019 novel coronavirus in the United States. First case of 2019 novel coronavirus in the United States. New England Journal of Medicine. 382(13):1199-207. https://doi.org/10.1056/NEJMoa2001316.

32. Heather A. Walter-McCabe. Coronavirus Pandemic Calls for an Immediate Social Work Response. Social Work in Public Health. 2020;35(3):69-72. doi:10.1080/19371918.2020.1751533. 